\title{
Pengaruh Motivasi dan Lingkungan Keluarga terhadap Minat Berwirausaha Mahasiswa
}

\section{Dijah Julindrastuti ${ }^{1}$, Iman Karyadi ${ }^{2}$, Sinta Sulistiani ${ }^{3}$}

1,2FEB Universitas Wijaya Kusuma Surabaya, Indonesia

${ }^{3}$ Universitas Pamulang, Tangerang Selatan, Banten, Indonesia

E-mail:dijah.julind@gmail.com,imamkaryadi121@gmail.com,dosen01876@unpam.ac.id

\begin{tabular}{l}
\hline Article Info \\
\hline Article History \\
Received: $2021-11-20$ \\
Revised: $2021-12-15$ \\
Published: $2022-01-23$
\end{tabular}

Published: 2022-01-23

Keywords:

Motivation;

Family environment;

Entrepreneurial Interest.

\begin{abstract}
This research is motivated by the current conditions where the high unemployment rate is due to limited employment opportunities. Entrepreneurship as an alternative that can be done by job seekers, especially college graduates where this does not only open up job opportunities for themselves but also for others, from this condition this research was conducted with the aim of knowing the influence of motivation and family environment on interest Entrepreneurship in Students. This research is a survey research. The population in this study are students of the Faculty of Economics and Business, Wijaya Kusuma University, Surabaya, with a sample of 114 respondents from management study programs in semester 2 and 4. Sampling using purposive sampling technique. Research data collection techniques were carried out through questionnaires, data analysis techniques included descriptive data analysis, Multiple Regression Analysis. The results showed that the family environment variable had an effect on the interest in entrepreneurship while the motivation variable had no effect on the student's interest in entrepreneurship.
\end{abstract}

\begin{abstract}
Abstrak
Penelitian ini dilatarbelakangi dengan kondisi yang terjadi saat ini dimana angka pengangguran yang tinggi dikarenakan lapangan pekerjaan yang terbatas. Wirausaha sebagai salah satu alternatif yang bisa dilakukan oleh para pencari kerja terutama lulusan perguruan tinggi dimana hal ini tidak hanya membuka peluang kerja terhadap dirinya tetapi juga untuk orang lain, dari kondisi inilah maka penelitian ini dilakukan dengan tujuan untuk mengetahui pengaruh motivasi dan lingkungan keluarga terhadap minat Berwirausaha pada Mahasiswa. Penelitian ini termasuk penelitian survei, populasi dalam penelitian ini adalah mahasiswa Fakultas Ekonomi dan Bisnis Universitas Wijaya Kusuma Surabaya dengan sampel mahasiswa program studi manajemen semester 2 dan 4 sejumlah 114 responden. Pengambilan sampel menggunakan teknik purposive sampling. Teknik pengumpulan data penelitian dilakukan melalui kuesioner, teknik analisa data meliputi analisa data diskriptif, Analisa Regresi Berganda. Hasil Penelitian menunjukan bahwa untuk variabel lingkungan keluarga berpengaruh terhadap minat berwirausaha sedangkan variabel motivasi tidak berpengaruh terhadap minat berwirausaha mahasiswa.
\end{abstract}

\section{PENDAHULUAN}

Indonesia merupakan salah satu negara di dunia yang memiliki penduduk dengan jumlah yang sangat banyak, kondisi ini bila dilihat dari sudut ketersediaan sumber daya manusia sebagai salah satu faktor yang ikut berperan dalam kegiatan perekonomian dan kekayaan negara akan tampak sebagai sesuatu yang menguntungkan bagi Indonesia, akan tetapi di sisi yang lain kondisi ini akan menjadi beban pemerintah untuk memikirkan pendidikan, kesehatan, tempat tinggal dan yang terpenting adalah pekerjaan sebagai sumber penghidupan. Indonesia sebagai negara berkembang sudah tentu membutuhkan banyak tenaga kerja terdidik yang memiliki keahlian, kondisi yang kita lihat saat ini kalau dari sisi ketersediaan tenaga kerja Indonesia sudah banyak memiliki tenaga-tenaga terampil, akan tetapi kalau kita lihat ketersediaan lapangan pekerjaan sangatlah kurang untuk bisa menampung para calon tenaga kerja. Terbatasnya lapangan pekerjaan ini membuat pemerintah harus berhadapan dengan tingginya angka pengangguran yang bisa membawa dampak sosial yang bisa berpengaruh terhadap sektor ekonomi, sosial dan keamanan, kondisi diatas memberikan gambaran pentingnya dunia entrepreneur. Pembangunan akan lebih berhasil jika ditunjang oleh para entrepreneur yang dapat membantu pemerintah dalam membuka lapangan pekerjaan, dalam melakukan pembangunan diperlukan dana yang 
cukup besar dimana kondisi ini bagi Pemerintah akan menjadi beban yang berat. Perguruan tinggi sebagai salah satu penghasil lulusan yang merupakan calon tenaga kerja dimana lulusan tersebut akan berhadapan dengan kondisi minimnya lowongan pekerjaan. Para lulusan diharapkan tidak hanya berorientasi sebagai pencari kerja (job seeker), namun dapat dan siap menjadi pencipta pekerjaan (job creator), (my sari,2013:2)

Kewirausahawan merupakan salah satu motor penggerak serta dapat menjadi solusi bagi permasalahan yang melanda dunia bisnis dan ekonomi suatu negara tanpa terkecuali Indonesia. Oleh karena itu sudah selayaknya dilakukan upaya untuk menumbuhkannya, seperti misalnya melalui dunia pendidikan serta berbagai kemudahan dalam mendirikan sebuah bisnis baru sehingga akan lebih banyak orangorang yang tersedia memilih jalan hidup sebagai seorang wirausahwan. Namun kesuksesan dalam berwirausaha tidak hanya sematamata ditentukan oleh berlimpahnya fasilitas serta kemudahan yang tersedia (antaranews.com,24 Oktober 2015). Kewirausahaan (entrepreneurhip) merupakan persoalan penting didalam perekonomian suatu bangsa yang sedang berkembang, kemajuan atau kemunduran ekonomi suatu bangsa salah satunya ditentukan oleh keberadaan dan peranan dari para wirausahawan ini, seluruh proses perubahan ekonomi tergantung dari orang yang menyebabkan timbulnya perubahan tersebut yakni sang "entrepreneur". Perusahaan yang sedang tumbuh dan yang bersifat inovatif menunjukan suatu jiwa (spirit) entrepreneur. Korporasi-korporasi berupaya untuk mendorong para manajer mereka menjadi orang-orang yang berjiwa entrepreneur, perguruan tinggi saat ini juga sedang mengembangkan program-program entrepreneurhip dan entrepreneur individual menimbulkan perubahan dalam kehidupan masyarakat.

Kewirausahaan (entrepreneur) berperan penting dalam mengembangkan pertumbuhan sosial ekonomi suatu negara, kewirausahaan berperan dalam membantu menyediakan begitu banyak kesempatan kerja yang yang akan berpengaruh pada kesejahteraan dan tingkat kompetisi suatu negara dalam menghadapi globalisasi yang yang membutuhkan kreativitas dan inovasi yang tinggi untuk menghadapi kompetensi global. Kewirausahaan merupakan suatu kemampuan dalam menciptakan nilai tambah di pasar melalui proses sumber daya dengan cara-cara baru dan berbeda, seorang wirausahawan adalah seorang yang memiliki keahlian dalam banyak aspek diantaranya keahlian untuk menjual mulai dari menawarkan ide hingga komoditas baik berupa produk atau jasa, dengan jiwa kreatifitasnya wirausahawan mampu berinovasi dan beradaptasi dengan berbagai situasi dan kondisi lingkungan. Banyak hal yang melatarbelakangi mereka-mereka yang memutuskan untuk berwirausaha diantaranya adalah karena PHK serta ada juga yang memang tertarik untuk membuka usaha sendiri beberapa alternatif pilihan usaha baru adalah waralaba (franchise), membeli usaha yang sudah berjalan, atau membuka usaha mulai dari nol.

Wirausaha yang berhasil diantaranya karena dukungan keluarga yang memang dari lingkungan wirausaha, Staw mengemukakan bahwa ada bukti kuat wirausahawan yang memiliki orang tua yang bekerja mandiri akan menularkan kemandirian yang ini akan menjadi motivasi untuk berwirausaha, profesi orang tua memiliki peran strategis sebagai budaya pembentuk motivasi berwirausaha. Krisis ekonomi yang pernah terjadi membuktikan kalau ternyata entrepreneur mampu bertahan menghadapi krisis ini karena permodalan mereka milik pribadi, menjadi seorang wirausaha memang tidaklah mudah, dibutuhkan ketahanan terhadap permasalahan yang muncul serta kemauan untuk mau berkembang dengan usaha sendiri dan kemampuan yang dimiliki, ada pendapat yang mengatakan seorang wirausaha lebih memiliki streetsmart dari pada booksmart, maksudnya adalah seorang wirausaha lebih mengutamakan untuk belajar dari pengalaman dibandingkan dengan belajar dari buku dan pendidikan formal, dengan kondisi yang terjadi saat ini dimana lowongan pekerjaan minim serta persaingan yang ketat maka pilihan berwirausaha terutama dikalangan para lulusan perguruan tinggi menjadi salah satu pilihan yang baik. Motivasi dan lingkungan keluarga diharapkan akan bisa memberikan dukungan untuk mereka memiliki minat dalam berwirausaha.

Latar belakang di atas maka dapat ditarik rumusan masalah apakah motivasi berpengaruh signifikan terhadap minat berwirausaha mahasiswa dan apakah lingkungan keluarga berpengaruh signifikan terhadap minat berwirausaha mahasiswa?.

\section{METODE PENELITIAN}

Penelitian ini merupakan penelitian yang membahas sebab akibat atau penelitian yang bersifat kausal komparatif. Menurut Sugiyono 
(2011: 37) hubungan kausal adalah hubungan yang bersifat sebab akibat, terdapat variabel independen (mempengaruhi) dan dependen (dipengaruhi), dari penelitian tersebut selanjutnya dicari pengaruhnya antara variabel independen yaitu motivasi dan Lingkungan Keluarga terhadap variabel dependen yaitu Minat Berwirausaha. Penelitian yang dilaku-kan adalah penelitian kuantitatif, menurut Sugiyono (2011: 8) penelitian kuantitatif merupakan metode penelitian yang ber-landaskan pada filsafat positivisme, digunakan untuk meneliti pada populasi atau sampel tertentu, pengumpulan data menggunakan instrumen penelitian, analisis data bersifat kuantitatif/ statistik, dengan tujuan untuk menguji hipotesis yang telah ditetapkan.

1. Populasi

Menurut Sugiyono (2011: 80) populasi adalah wilayah generalisasi yang terdiri atas objek/ subjek yang mempunyai kualitas dan karakteristik tertentu yang ditetapkan oleh peneliti untuk dipelajari dan kemudian ditarik kesimpulannya, dalam penelitian ini, ditentukan bahwa populasinya adalah mahasiswa Fakultas Ekonomi dan Bisnis Universitas Wijaya Kusuma Surabaya.

2. Sampel

Menurut Sugiyono (2011), sampel adalah bagian dari jumlah dan karakteristik yang dimiliki oleh populasi, sample merupakan bagian yang berguna bagi tujuan penelitian populasi dan aspek-aspeknya. Teknik penarikan sampel dalam penelitian ini menggunakan jenis non probability sampling, jenis sampel ini tidak dipilih secara acak, tidak semua unsur atau elemen populasi mempunyai kesempatan sama untuk bisa dipilih menjadi sampel. Unsur populasi yang terpilih menjadi sampel bisa disebabkan karena kebetulan atau karena faktor lain yang sebelumnya sudah direncanakan oleh peneliti, teknik penentuan sampel yang digunakan adalah Purposive Sampling dimana penelitian ini tidak dilakukan pada seluruh populasi, tapi terfokus pada target. Purposive Sampling artinya bahwa penetuan sampel mempertimbangkan kriteria-kriteria tertentu yang telah dibuat terhadap obyek yang sesuai dengan tujuan penelitian. Sampel dalam penelitian ini adalah mahasiswa jurusan manajemen semester 2 dan 4 Fakultas Ekonomika dan Bisnis Universitas Wijaya Kusuma Surabaya.
Analisa data yang digunakan dalam penelitian ini adalah:

1. Analisis Statistik Deskriptif

Analisis ini digunakan untuk menganalisis data dengan cara mendes-kripsikan atau mengambarkan data yang telah terkumpul sebagaimana adanya tanpa ber-maksud membuat kesimpulan yang berlaku untuk umum atau generalisasi (Sugiyono, 2011: 147). Statistika deskriptif menjelaskan berbagai karakteristik data seperti mean, median, modus, standar deviasi, nilai maksimum dan nilai minimum, selanjutnya data yang diperoleh disajikan dalam bentuk tabel, histogram maupun pie chart untuk setiapvariabel penelitian.

2. Analisa Regresi Berganda

Analisis ini digunakan untuk menaksir bagaimana keadaan (naik turunnya) variabel dependen, bila dua atau lebih variabel dependen sebagai faktor predictor dimanipulasi (dinaik turunkan nilainya). (Sugiyono, 2011). Bila dijabarkan secara matematis bentuk persamaan dari regresi linier berganda adalah sebagai berikut:

$Y=\alpha+\beta X 1+\beta X 2+\varepsilon$

3. Uji F

Uji f dipakai untuk menilai kelayakan dari model dimana apabila $f$ signifikan berarti model layak untuk memprediksi Y.

4. Uji t

Uji hipotesis t-test digunakan untuk mengetahui apakah variabel bebas signifikan atau tidak terhadap variabel terikat secara individual untuk setiap variabel (Sugiyono, 2010), nilai t-hitung hasil perhitungan ini selanjutnya dibandingkan dengan ttabel dengan menggunakan tingkat kesalahan 0,05. Kriteria yang digunakan sebagai dasar perbandingansebagai berikut:

$\mathrm{Ha}=$ diterima jika nilai $-\mathrm{ttabel}<$ thitung $<\mathrm{ttabel}$ $\mathrm{Ho}=$ ditolak jika nilai thitung $>\mathrm{t}$ tabel atau $\mathrm{t}$ hitung $<-t$ table.

Bila terjadi penerimaan Ho maka dapat disimpulkan suatu pengaruh adalah tidak signifikan, sedangkan bila Ho ditolak artinya suatu pengaruh adalah signifikan. Ranca-ngan pengujian hipotesis penelitian ini untuk menguji ada tidaknya pengaruh anta-ra variabel independent $(\mathrm{X})$ yaitu moti-vasi(X1), lingkungan keluarga (X2) terhadap minat berwirausaha sebagai variabel depen-den $(Y)$. 


\section{HASIL DAN PEMBAHASAN}

Prodi Manajemen S1 Fakultas Ekonomi Dan Bisnis Universitas Wijaya kusuma Surabaya mempunyai mahasiswa semester 2 dan 4 sebanyak kurang lebih 350 orang, kemudian yang di ambil sampelnya sebagai responden adalah 114 orang, kuesioner yang disebarkan berjumlah 125 kuesioner. Kuesioner yang kembali adalah 125 yang memenuhi syarat untuk diolah adalah 114 kuesiuoner dibawah ini disampaikam 3 (tiga) profil responden, yaitu: jenis kelamin, semester dan status.

Tabel 1. Identifikasi Responden Berdasarkan Jenis Kelamin

\begin{tabular}{lcc}
\hline Jenis Kelamin & Frekuensi & $\mathbf{\%}$ \\
\hline Pria & 42 & 37 \\
\hline Wanita & 72 & 63 \\
\hline Total & 114 & 100 \\
\hline
\end{tabular}

Tabel 2. Identifikasi Responden Berdasarkan Semester

\begin{tabular}{lcc}
\hline Semester & Frekuensi & $\mathbf{\%}$ \\
\hline Dua (II) & 78 & 68 \\
\hline Empat (IV) & 36 & 32 \\
\hline Total & 114 & 100 \\
\hline
\end{tabular}

Tabel 3. Identifikasi Responden Berdasarkan Status

\begin{tabular}{lcc}
\hline Status & Frekuensi & \% \\
\hline Tidak Bekerja & 94 & 82 \\
\hline Bekerja & 20 & 18 \\
\hline Total & 114 & 100 \\
\hline
\end{tabular}

Statitik Deskriptif Variabel Penelitian

Rumus untuk kategorisasi rerata variabel adalah sebagai berikut:

$\frac{\text { Nilai Tertinggi }- \text { Nilai Terendah }}{4}=\frac{4-1}{4}=\frac{3}{4}=0,75$

Keterangan:

Skor $1,00-<1,75=$ Sangat rendah

Skor $1,75-<2,50=$ Rendah

Skor 2,50 $-<3,25=$ Tinggi

Skor 3,25 - 4,00 = Sangat tinggi

Rata-rata minat berwirausaha mahasiswa sebesar 2,7311, berarti berada dalam range 2,53,25 yang termasuk tinggi, dengan demikian dapat dikatakan bahwa minat berwirausaha mahasiswa termasuk tinggi, rata-rata motivasi sebesar 2,7867, berarti berada dalam range 2,53,25 yang termasuk tinggi, dapat dikatakan bahwa motivasi mahasiswa untuk berwirausaha termasuk tinggi. Rerata lingkungan keluarga 2,6339 berarti berada dalam range 2,5-3,25 yang termasuk tinggi, dengan demikian dapat dikatakan bahwa lingkungan keluarga mahasiswa untuk berwirausaha termasuk tinggi.

Hasil uji $\mathrm{F}$ dapat dilihat dari tabel uji $\mathrm{F}$, menunjukkan signifikansi sebesar 0,000005 lebih kecil dari 0,05, dengan demikian $\mathrm{Ha}$ diterima, dapat dikatakan model fit (variabel motivasi dan lingkungan keluarga dapat digunakan untuk memprediksi minat berwirausaha).

Tabel 4. Uji F dengan ANOVA

\begin{tabular}{rlclcc}
\hline Model & $\begin{array}{l}\text { Sum of } \\
\text { Squares }\end{array}$ & df & $\begin{array}{l}\text { Mean } \\
\text { Square }\end{array}$ & F & Sig. \\
\hline Regression & 7.500 & 2 & 3.750 & 316.467 & $.000^{\mathrm{a}}$ \\
\hline Residual & 1.315 & 111 & .012 & & \\
\hline Total & 8.816 & 113 & & & \\
\hline a. & Predictors: (Constant), Lingkungan, Motivasi \\
b. & Dependent Variable: Minat wirausaha &
\end{tabular}

Dari tabel uji $\mathrm{t}$ berikut ini diketahui bahwa signifikansi motivasi sebesar 0,098 > 0,05, dengan demikian HO diterima, hal itu berarti motivasi tidak berpengaruh signifikan terhadap minat berwira-usaha mahasiswa. Dari tabel uji t diketahui bahwa signifikansi lingkungan keluarga sebesar $0,000<0,05$, dengan demikian Ha diterima, hal itu berarti lingkungan keluarga berpengaruh signifikan terhadap minat berwirausaha maha-siswa.

Tabel 4. Hasil Uji T Regresi Linear Berganda

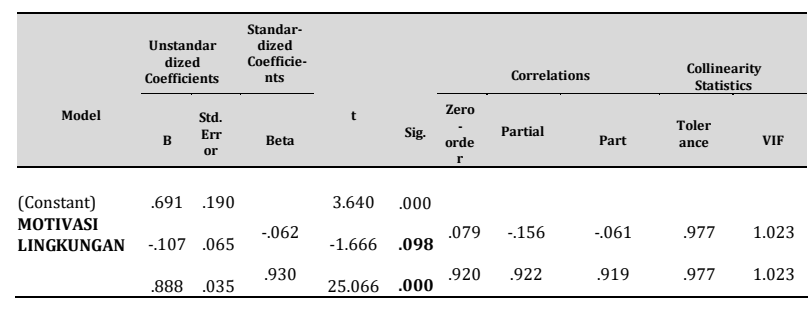

Dari tabel uji $t$ diketahui bahwa persamaan regresi linear berganda adalah $Y=a+b 1 X 1$ dan b2X2, minat berwirausaha $=0,691-0,107$ motivasi $+0,888$ lingkungan keluarga, dari konstanta (a) sebesar 0,691, dapat dikatakan bahwa jika tidak ada motivasi mahasiswa dan tidak ada dukungan lingkungan keluarga mahasiswa, maka mahasiswa tidak mempunyai minat berwirausaha, sedangkan koefisisen regresi (b1) motivasi sebesar -0,107 menunjuk-kan hubungan yang negatif antara motivasi dan minat berwirausaha, namun dari hasil signifikansi uji $\mathrm{t}$ diketahui bahwa motivasi tidak berpengaruh signifikan terhadap minat berwirausaha, dengan demikian berarti kenai-kan atau penurunan (besar kecilnya) motivasi tidak bepengaruh pada kenaikan atau penuru-nan (besar kecilnya) minat berwirausaha, untuk 
koefisien regresi (b2) lingkungan keluarga menunjukkan angka sebesar 0,888, dengan demikian lingkungan keluarga berpengaruh positif terhadap minat berwirausaha. Hal itu berarti hubungan yang searah, jika lingkungan keluarga naik (tinggi), maka minat berwirausaha juga naik (tinggi), sebaliknya jika lingkungan keluarga turun (rendah), maka minat berwirausaha juga turun (rendah). Oleh karena itu lingkungan keluarga mahasiswa perlu mendapat perhatian supaya dapat meningkatkan minatmahasiswa untuk berwirausaha.

Berdasarkan pengujian hipotesis 1 dimana dalam hipotesis 1 disampaikan bahwa motivasi berpengaruh terhadap minat berwirausaha mahasiswa adalah tidak terbukti atau motivasi tidak berpengaruh terhadap minat berwirausaha mahasiswa, tidak berpengaruhnya motivasi ter-hadap minat berwirausaha ini dikarenakan ada faktor yang lebih dominan yang berpengaruh terhadap minat berwirausaha diantaranya kondisi yang dihadapi mahasiwa dimana mereka memang sudah memiliki kebiasaan melakukan bisnis untuk mendapatkan tambahan biaya perkuliahan ataupun mereka yang mencoba berbisnis karena menginginkan pendapatan yang bisa dipakai untuk memenuhi keinginan mereka untuk fashion ataupun untuk sekedar menambah uang saku ataupun karena memang mahasiswa sudah berada dalam lingkungan yang mendu-kung dia untuk berwirausaha seperti misalnya dari orang tua yang memang sudah bekerja sebagai wirausaha. Kondisi inilah yang terkadang tanpa disadari secara tidak langsung sudah mem-bentuk mahasiswa untuk berwirausaha.

Hasil Pengujian hipotesis ke 2 yang menyatakan bahwa lingkungan keluarga berpengaruh terhadap minat berwirausaha mahasiswa dapat dibuktikan kebenarannya, hal ini berarti menunjukkan jika lingkungan keluarga meningkat berarti minat berwirausaha juga akan meningkat dan sebaliknya kalau lingkungan keluarga menurun maka minat berwirausaha juga akan menurun.

Dari hasil pengujian kedua hipotesis tersebut bisa dilakukan analisa bahwa tidak adanya pengaruh motivasi terhadap minat berwirausaha dan lingkungan keluarga yang berpengaruh bisa dikarenakan lingkungan keluarga yang memiliki peran secara tidak langsung dalam membentuk kepribadian dan pola pikir serta kebiasaan mahasiswa dimana kalau dikaitkan dengan ilmu physchologi bahwasannya lingkungan dimana seorang individu berada akan memiliki peran dalam mempengaruhi pola pikir dan kebiasaan individu, dari penjelasan inilah bisa dipakai untuk memberikan penjelasan terkait pembuktian untuk kedua hipotesis tersebut.

\section{SIMPULAN DAN SARAN}

\section{A. Simpulan}

Berdasarkan pemaparan pada penelitian ini dapat disimpulkan bahwa pendekatan Interdisipliner yaitu suatu pendekatan dalam pemecahan suatu masalah dengan menggunakan tinjauan berbagai sudut pandang ilmu serumpun yang relevan atau tepat guna secara terpadu. Integratif Interkonektif sendiri didasarkan pada paradigma agama dan sains integratif interkonektif atau paradigma kesatuan dan ter-padu/non dikotomik antara agama dan sains, untuk mewujudkannya dilakukan dengan mem-posisikan dan menghubungkan agama dan sains secara tegas dan jelas. Paradigma integrasi-interkoneksi ini merupakan jawaban atau respon terhadap kesulitankesulitan selama ini, karena terpisahnya ilmu umum dan imu agama, dari paradigma tersebut dapat kita pahami bahwa setiap bangunan keilmuan apapun bak ilmu agama, sosial, humaniora, kealaman, psikologi dan lain sebagainya tidak bisa bersifat single entity. Masing-masing dari ilmu tersebut saling membutuhkan satu sama lain yang dapat membantu manusia dalam memahami kompleksitas kehidupan dan memecahkan persoalan yang ada.

Fungsi paradigma adalah memberikan kerangka, mengarahkan, dan menguji consistensi dari proses keilmuan, paradigma merupakan kerangka logis dari teori sehingga satu para-digma bisa melingkupi beberapa teori meskipun paradigma lahir dari akumulasi teori-teori yang saling mendukung dan saling menyempurnakan serta menjadi satu kebutuhan dan sebuah konsisten yang utuh, sebaliknya dari suatu paradigma ilmu dapat dilahirkan teori-teori baru berdasarkan temuan-temuan para ilmu-wan. Berdasarkan pada hasil analisis data dan pembahasan yang telah dipaparkan pada bab sebelumnya, maka dapat ditarik kesimpulan bahwa Lingkungan keluarga secara signifikan berpengaruh positif terhadap minat berwirausaha mahasiswa, dimana hal in mengandung arti bahwa setiap peningkatan lingkungan keluarga akan mengakibatkan minat berwirausaha pada Mahasiswa Manajemen Fakultas Ekonomi dan Bisnis 
ikut meningkat. Motivasi tidak berpengaruh terhadap minat berwirausaha.

\section{B. Saran}

Berdasarkan hasil penelitian dan simpulan yang ada, maka saran yang diberikan peneliti adalah bagi Mahasiswa Manajemen Fakultas Ekonomi dan Bisnis Universitas Wijaya Kusuma agar dapat mewujudkan minat berwirausaha denganmengembangkan hobby untuk bisa lebih menekuni dan mengem-bangkan usaha yang pada akhirnya secara tidak langsung akan memberikan penghasilan yang bisa dimanfaatkan untuk pemenuhan kebutuhan mahasiwa yang bersang-kutan. Selain hal tersebut diatas kegiatan itu bisa dikembangkan dengan mendirikan UMKM dengan pihak lain sehingga hal ini juga akan turut membantu pemerintah untuk menyediakan lapangan kerja, saran lain yang bisa peneliti sampaikan adalah bagi peneliti selanjutnya bisa mengembangkan penelitian ini dengan memakai variabel yang lain seperti misalnya resiko, sikap ataupun kepribadian.

\section{DAFTAR RUJUKAN}

Basrowi. (2011). Kewirausahaan Untuk Peguruan Tinggi. Bandung: Alfabeta.

Baum, J. R., Frese, M., \& Baron, R. A. (2007). The psychology of entrepreneurship.

Business Management. Prentice Hill Upper Saddle River, NJ.

Bygrave, William. (1996). Entrepreneurship. Binarupa Aksara. Jakarta.

Campbell, John P. (2002). Modeling the Performance Prediction Problem in Industrial and Organizational Psychology, Handbook of Industrial and Organizational Psychology, Volume 1, ed. Marvin D. Dunnette and Leaette M. Hough. Jaico Publishing House.Mumbai.

Hendro. (2011). Dasar-Dasar Kewirausahaan. Erlangga. Jakarta. id=12093\&mid $=26055$, pada 20-04-12.

Purwanto, M. Ngalim. 2006. Psikologi Pendidikan. PT, Remaja.Bandung.
Pusat Bahasa Departemen Pendidikan Nasional. (2011). Kamus Besar Bahasa Indonesia.Balai Pustaka.Jakarta.

Sarosa, P. (2005). Kiat Praktis Membuka Usaha. Becoming Young Entrepreneur:Dream Big Start Small, Act Now! Panduan Praktis \& Motivasional Bagi

Sekaran. (1992).Research Methods for Business. Third Edition.Southern Illonis University Shane S., Locke E.A \& Collins C.J. (2003). Entrepreneurial Motivation, Human Resource

Sofyan, H. \& Uno, B.H. (2004). Teori Motivasi dan Aplikasinya dalam Penelitian.

Sugiyono. (2011). Metode Penelitian Kuantitatif Kualitatif R\&D. Edisi 13. Bandung: Alfabeta.

Sujanto, A. (2004). Psikologi Umum. Jakarta: Aksara.

Suprihatin, L., \& Sunarsi, D. (2021). Pengaruh Kepemimpinan Transaksional dan Lingkungan Kerja Terhadap Kinerja Pegawai di Pusat Pendidikan dan Pelatihan Pegawai Kementerian Pendidikan dan Kebudayaan. JIIP - Jurnal Ilmiah Ilmu Pendidikan, 4(1), $\quad$ 78-86. https://doi.org/10.54371/jiip.v4i1.207

Suryana, Y. \& Bayu, K. (2010). Kewirausahaan Pendekatan Karakteristik Wirausahawan Sukses. Jakarta: Kencana.

Walgito, B. (1999). Psikologi Sosial: Suatu Pengantar. Yogyakarta: ANDI.

Wanto, S.F. (2014). Hubungan Kemandirian dan Motivasi Berwirausaha dengan Minat Berwirausaha Siswa Kelas SMK N 1 Seyegan. (Skripsi). Yogyakarta

Winkel. (2004). Psikologi Pengajaran. Media Abadi.Yogyakarta.

Yusuf, Syamsu. 2012. Perkembangan Peserta Didik.Jakarta: Raja Grafindo Persada Zimmer, T.W. \& Scarborough, N.M. 2001.Essentials of Entrepreneurship and Small 